NASA Technical Memorandum 107238

AIAA-96-2908

\title{
High Temperature Brush Seal Tuft Testing of Metallic Bristles Versus Chrome Carbide
}

James A. Fellenstein

Ohio Aerospace Institute

Cleveland, Ohio

Christopher DellaCorte

Lewis Research Center

Cleveland, Ohio

Kenneth D. Moore

Pratt \& Whitney

West Palm Beach, Florida

Esther Boyes

Pratt \& Whitney

East Hartford, Connecticut

Prepared for the

32nd Joint Propulsion Conference

cosponsored by AIAA, ASME, SAE, and ASEE

Lake Buena Vista, Florida, July 1-3, 1996 


\section{HIGH TEMPERATURE BRUSH SEAL TUFT TESTING OF METALLIC BRISTLES VERSUS CHROME CARBIDE}

\author{
James A. Fellenstein* \\ Ohio Aerospace Institute \\ 22800 Cedar Point Road \\ Cleveland, Ohio 44142 \\ Kenneth D. Moore
Pratt \& Whitney
P.O. Box 109600
West Palm Beach, Florida 33410
}

Abstract

The tribology of brush seals is of considerable interest to turbine engine designers because bristle wear continues to limit long term seal performance and life. To provide better materials characterization and foster the development of improved seals, NASA Lewis has developed a brush seal tuft tester. In this test, a "paintbrush" sample tuft is loaded under constant contact pressure against the outside diameter of a rotating journal. With this configuration a direct measurement of load and friction is made. Accurate wear rate measurements are possible due to the known contact pressure. Previously reported baseline research using this facility showed good data repeatability and wear morphology similar to published seal data.

This paper extends and expands the database for candidate brush seal materials. A series of tuft tests were completed to evaluate the performance of five high temperature superalloy wires sliding against plasma sprayed nichromebonded chrome carbide. Wire materials were either nickel-chrome or cobalt-chrome based superalloys. Good corroboration of the tuft results with dynamic seal rig tests was observed; giving additional confidence in the tuft test as a screening and development tool.

\author{
Christopher DellaCorte \\ NASA Lewis Research Center \\ 21000 Brookpark Road \\ Cleveland, Ohio 44135 \\ Esther Boyes \\ Pratt \& Whitney \\ 400 Main Street \\ East Hartford, Connecticut 06108
}

\section{Introduction}

Tribology continues to be a key technical obstacle facing long life brush seals. The interfacial sliding contact between the brush and shaft represents a challenging and intriguing engineering problem. Studies have shown that the optimal sealing characteristics for a brush seal occur before the interference fit between the brush and shaft is excessively worn' ${ }^{1}$. However, hard coatings which are applied to the shaft to reduce shaft wear tend to cause a high brush wear rate resulting in a premature increase in seal leakage and reduced overall turbine engine efficiency. Hence, designers are faced with the dilemma of minimizing potentially dangerous shaft wear while reducing excessive brush wear. Brush seal designers are also faced with a limited number of material choices due to the severe operating conditions found in a turbine engine. Typical design conditions for state-of-the-art brush seals are $700^{\circ} \mathrm{C}\left(1300{ }^{\circ} \mathrm{F}\right)$ and $305 \mathrm{~m} / \mathrm{s}(1000 \mathrm{ft} / \mathrm{s})$ with pressure differentials of 550 to $690 \mathrm{kPa}$ (80 to 100 psi) per sealing stage. Typical material candidate pairs for these applications include a cobalt-based brush and nichrome-bonded chrome carbide shaft coating. With the goal of improved turbine engine efficiency pushing turbine engine temperatures and seal pressure differentials higher, future seal goals are $815^{\circ} \mathrm{C}\left(1500{ }^{\circ} \mathrm{F}\right), 500 \mathrm{~m} / \mathrm{s}$ $(1650 \mathrm{ft} / \mathrm{s})$, and $960 \mathrm{kPa}(140 \mathrm{psi})$ per stage 2 .

To date, various experimental methods have been used to characterize the tribology of brush seals. Most of the relevant tribological database has been obtained from full scale seal tests conducted with the primary goal of determining the leakage characteristics of a seal ${ }^{3-7}$. However, from a

*NASA Resident Research Associate at Lewis Research Center.

Copyright 1996 by Ohio Aerospace Institute. Published ty the American Insitute of Aeronautics and Astronautics, Inc. with permission. 
tribological point of view, these tests include the confounding effects of varying contact pressures, bristle flaring, high temperature oxidation, and varying bristle contact angles. Tribological testing has also been completed on miniature brush seals ${ }^{8}$. Although these tests are designed with actual seal hardware, quantifying brush wear is made difficult by many of the same confounding factors found in full scale seal testing.

Another alternative is to test small samples of brush material (a tuft) against a rotating shaft. By employing this method, the difficulties associated with quantifying the tribological characteristics of brush seals are overcome. In tuft testing, the bristles are packed together at a specified contact angle and wear measurements can be made optically by using witness marks inscribed into the bristles. Interface contact pressures can be either constant or varying depending on the tuft mounting device. Unsteady bristle wear and flaring caused by an applied pressure differential in full scale seal testing are avoided.

The first published successful tuft testing was completed by Hawthome 9 using a tuft-on-disc configuration. In this study various polymeric, ceramic, or metallic wire samples were tested against coated and uncoated steel discs. The coatings included nichrome-bonded chrome carbide, chrome oxide, and an early version of a NASA solid lubricant. The "best" tribological results from this study were obtained with a nickel-based superalloy wire run against nichrome-bonded chrome carbide. This combination was followed closely by a cobaltbased superalloy against the nichrome-bonded chrome carbide. These results are in general agreement with the high temperature tests completed by Atkinson and Bristol6.

Concurrent to Hawthome's efforts, a tuft tester with a test geometry similar to a block-on-ring was being developed at the NASA Lewis Research Center. As previously reported, this test facility has provided excellent tribological results which have been corroborated by full scale brush seal tests 10 . The initial study was conducted with cobalt-based superalloy bristles run against a bare nickel-based superalloy journal. Test variables were test temperature $\left(20\right.$ or $650^{\circ} \mathrm{C}$ ), surface speed ( 2 or 24 $\mathrm{m} / \mathrm{s})$, and contact force $(0.5$ or $1.0 \mathrm{~N})$. In this study, it was hypothesized that the formation of a lubricous oxide layer at $650^{\circ} \mathrm{C}$ was responsible for the drop in friction and lower brush and journal wear rates at elevated temperatures. Friction and both component wear rates were also determined to decrease with increased surface speed. Baseline data from this initial study has been included in this paper for comparative purposes.

In the present studies, a cooperative program was instituted to test five metallic wire candidates versus a plasma sprayed nichrome-bonded chrome carbide at $650^{\circ} \mathrm{C}\left(1200^{\circ} \mathrm{F}\right)$. Unlike previously reported baseline testing, only high temperature testing was completed on the new materials. This was done because the high temperature testing provides a better simulation of the actual turbine engine environment for brush seals. The wire materials used during this collaboration were either nickel-chrome or cobalt-chrome based superalloys. Comparison of the tuft test results to full scale brush seal tests will be made to verify the advantages of tuft testing brush seal materials before full scale seals are produced and tested.

\section{Tuft Testing}

\section{Specimen - Materials and Preparation}

Tuft Specimens. The five wire materials chosen for this work are designated $\mathrm{H} 25, \mathrm{H} 214$, H230, I718, and MA754. The weight percent composition and some of the high temperature properties of each material are listed in Tables 1 and 2. These materials were chosen for their high temperature capabilities and their availability in wire form.

Each tuft is made with approximately 920 bristles TIG welded into a superalloy collar. The wire diameter for each material was $0.071 \mathrm{~mm}$ (0.0028 in). Before testing, each tuft is diamond ground to a $45^{\circ}$ contact angle and ultrasonically cleaned in consecutive five minute baths of acetone and methyl alcohol. A schematic of a typical brush seal tuft is shown in Figure 1.

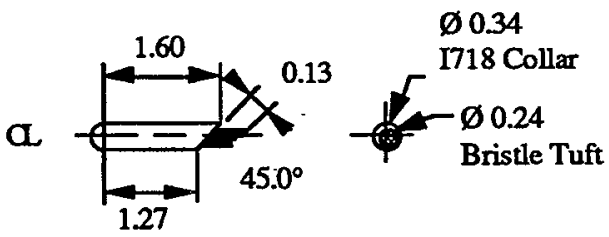

Figure 1 : Tuft specimen configuration showing dimensions and geometry (dimensions are in $\mathrm{cm}$ ).

Journal Specimens. Each of the journals used for this research was plasma sprayed with 75-25 wt. \% chrome carbide to nichrome binder. After spraying, the coatings were diamond ground to an average final surface roughness of $0.2 \mu \mathrm{m}(8 \mu \mathrm{in}) \mathrm{Ra}$ with a total coating thickness between $0.102 \mathrm{~mm}$ (0.004 in.) and $0.152 \mathrm{~mm}(0.006 \mathrm{in}$.). Figure 2 shows the geometry and dimensions of a typical sprayed journal. Each joumal can accommodate five wear tracks which are approximately $3 \mathrm{~mm}$ wide. Before the initial run of each test, the journals are cleaned to remove any residual contaminants. This process includes washing in ethyl alcohol, scrubbing with levigated alumina and finally rinsing with distilled water. 

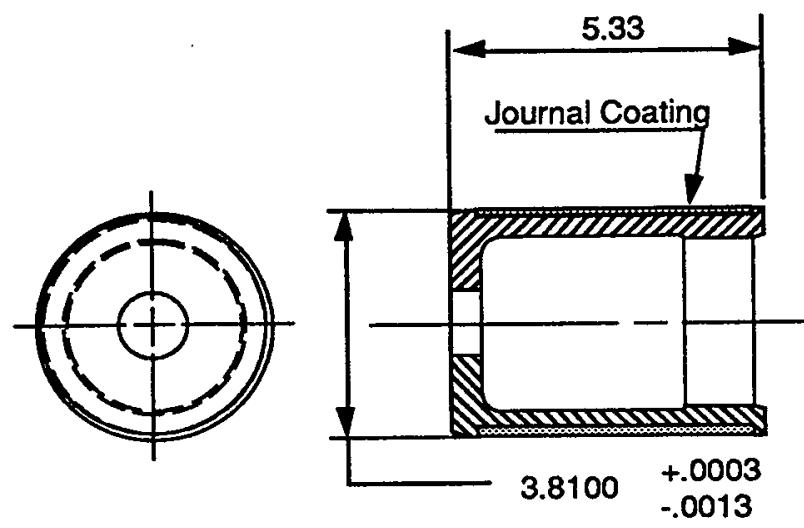

Figure 2: Journal specimen configuration showing dimensions and geometry (dimensions are in $\mathrm{cm}$ ).

\section{Test Apparatus and Procedure}

Test Apparatus. A cross sectional view of the brush seal tuft tester is shown in Figure 3. The maximum test spindle speed and test temperature are $17,000 \mathrm{RPM}$ and $700^{\circ} \mathrm{C}\left(1292{ }^{\circ} \mathrm{F}\right)$ respectively. A two degree of freedom gimbal holds the tuft against the journal with a constant contact pressure. The gimbal has a counter weight with a fine adjustment for system balancing and a low stiffness paddle damper for reducing any high frequency noise. The system is sensitive enough that a two gram weight can topple the gimbal. Also, when mounting the test journals the total indicated runout was limited to less than $0.009 \mathrm{~mm}(0.00035 \mathrm{in}$.). Additional test facility information is available in reference ${ }^{10}$.

Tuft Test Procedure and Analysis. Two tufts were made from each of the five wire materials. Each tuft was tested for fifty hours against a chrome carbide coated journal. Interim wear measurements were also completed after twenty-five hours. Table 3 lists the standardized test conditions used for these

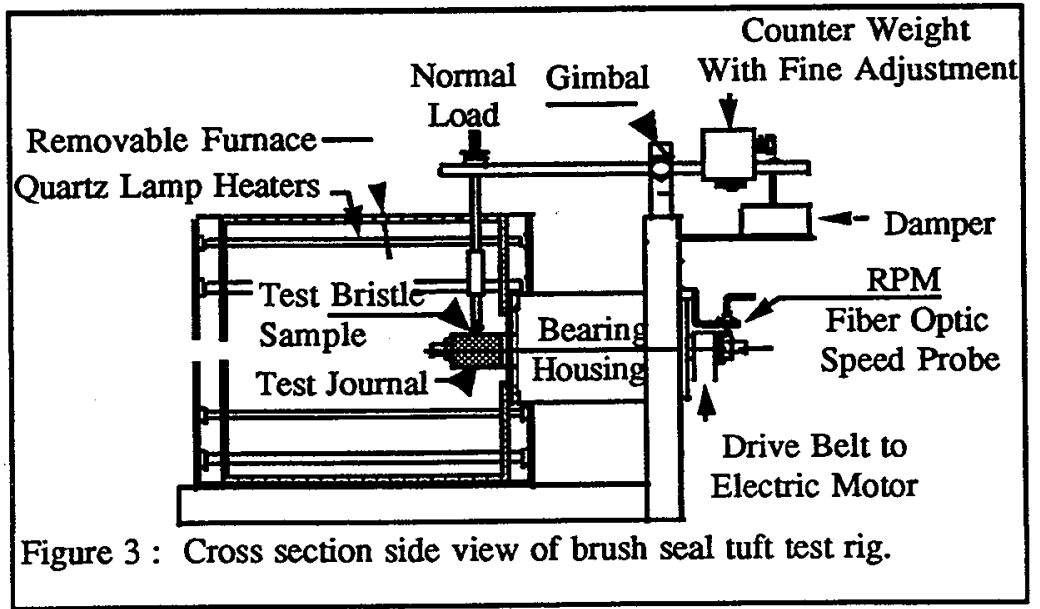

experiments.

During a test, the frictional force, temperature, and speed are recorded every six minutes by a computer data acquisition system. The recorded friction force represents an average of 300 samples taken over a fifteen second period. This average value is then divided by the test load to determine the coefficient of friction. These three test measurements are taken using a \pm 250 gram linear voltage displacement transformer (LVDT), a Type $K$ thermocouple and an optical speed pick-up.

Brush wear is determined by measuring the bristle length from an inscribed witness mark to the bristle ends before and after each test. The measurements are completed by taking pre and post test photomacrographs at a magnification of $25 \mathrm{X}$. Eight reference locations are recorded and averaged to find the mean brush wear per test interval. This value is multiplied by the cross sectional area of the sample to determine the mean wear volume. Finally, the wear factor is calculated based on the wear volume divided by the test load and sliding distance. Weight loss measurements are not used to estimate wear due to the confounding effects of oxidation (weight gain).

Post test analysis of the journals was completed by measuring the circumferential wear track cross sectional area with a stylus type surface profilometer at $90^{\circ}$ intervals around the journal. Starting and ending points for each trace are noted by either well defined shoulders in the profilometer trace or by visual inspection during the trace with a video camera. After completing the four traces, the average wear area is calculated and multiplied by the journal circumference to determine the wear volume. Again, the wear factor is determined by dividing the wear volume by the test load and sliding distance.

\section{Results and Discussion}

Friction Coefficient. Friction coefficients at $650^{\circ} \mathrm{C}\left(1200^{\circ} \mathrm{F}\right)$ ranged from a high of 0.32 for $\mathrm{H} 25$ to 0.14 for MA754. The average friction coefficient for each of the test configurations is presented in Figure 4. Also, included in Figure 4 are the test results for $\mathrm{H} 25$ and $\mathrm{H} 214$ tufts run against bare 1718 journals. As seen in Figure 4, the two alloys with the highest Nickel content (MA754 and $\mathrm{H} 214)$ had the lowest friction coefficients against the nichromebonded chrome carbide. Due to the constant contact pressure, the coefficient of friction was constant during each test. In full scale tests, the friction force is time dependent because of the changing contact 
force at the seal interface (i.e. as wear occurs, the interference preload and hence the friction force decreases).

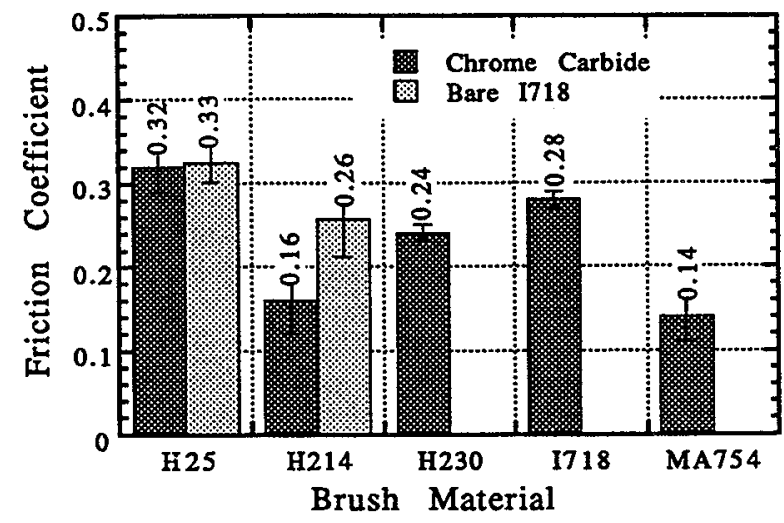

Figure 4 : Average friction coefficients for five metalic bristle materials tested against plasma sprayed chrome carbide and bare 1718 at $650^{\circ} \mathrm{C}$ $\left(1200^{\circ} \mathrm{F}\right)$.

Derby and England 8 recorded friction coefficients of 0.23 for $\mathrm{H} 25$ versus chrome carbide at similar speeds and test temperatures of $427^{\circ} \mathrm{C}$ $\left(800^{\circ} \mathrm{F}\right)$. Baseline friction coefficients for $\mathrm{H} 25$ against bare $\mathrm{I} 718$ at $20^{\circ} \mathrm{C}\left(68^{\circ} \mathrm{F}\right)$ and $650^{\circ} \mathrm{C}(1200$ $\left.{ }^{\circ} \mathrm{F}\right)$ are 0.42 and 0.32 respectively. In the initial testing, the drop in friction was attributed to the formation of a lubricous oxide layer on the 171811 .

Brush Wear, Only the H25 and 1718 successfully completed the fifty hour tests against the plasma sprayed chrome carbide. The brush wear factors for the $\mathrm{H} 25$ and 1718 were $4.6 \times 10^{-7}$ and $7.0 \times 10^{-7} \mathrm{~mm}^{3} / \mathrm{N} \cdot \mathrm{m}$. Even though the onset of flaring was observed in the H230 sample after 50 hours, the brush wear factor was estimated at $6.5 \times 10^{-7} \mathrm{~mm}^{3} / \mathrm{N} \cdot \mathrm{m}$. Both $\mathrm{H} 214$ tufts failed due to the flaring or buckling of the bristles after three hours of testing, therefore, no wear factor was calculated. After a combined total of 4.9 hours of testing both MA754 tufts were worn away. Baseline testing completed with a $\mathrm{H} 25$ tuft against bare $\mathrm{I718}$ resulted in a brush wear factor of $6.0 \times 10^{-7} \mathrm{~mm}^{3} / \mathrm{N} \cdot \mathrm{m}$. Figure 5 shows these test results compared to previously measured 1718 baseline data.

When ranking the five bristle materials, the two materials with the largest wt\% of Ni exhibited the poorest brush wear. MA754, with 78 wt\% Ni, failed due to the excessive wearing of the bristles. $\mathrm{H} 214$, with $75 \mathrm{wt} \% \mathrm{Ni}$, failed due to the flaring of the bristles. Figure 6 shows a H214 tuft after two hours of testing at $650^{\circ} \mathrm{C}\left(1200^{\circ} \mathrm{F}\right)$. Bristle buckling is caused by the constant contact force between the tuft and journal and is dependent on the high temperature compressive creep properties of the wire material. The poor performance of these two materials can be caused by the large weight percent of low strength nickel found in these alloys in

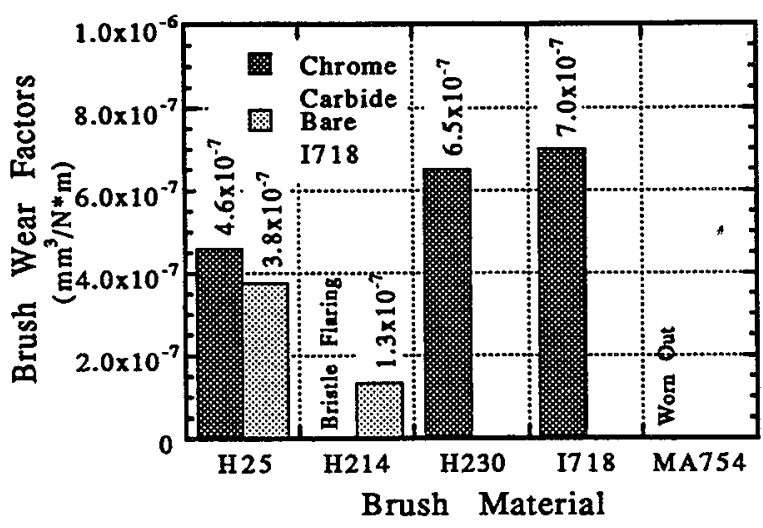

Figure 5 : Brush wear factors for five metalic wire samples tested against plasma sprayed chrome carbide and bare 1718 at $650^{\circ} \mathrm{C}\left(1200^{\circ} \mathrm{F}\right)$.

conjunction with the lack of a high temperature solid-solution hardener such as molybdenum or tungsten. The ultimate tensile strength and the $0.2 \%$ offset yield strength of nickel at $650^{\circ} \mathrm{C}\left(1200^{\circ} \mathrm{F}\right)$ are $153 \mathrm{Mpa}(22 \mathrm{Ksi})$ and $70 \mathrm{MPa}(10 \mathrm{Ksi})$ respectively. H230 and I718 have 52.7 and 52.5 wt\% nickel. However, the tensile strength and the $0.2 \%$ offset yield strength of 1718 are much higher than the H230. This may be the reason why the tribological characteristics of the two alloys are approximately the same but their longevity as a brush seal is different. A complicating factor in considering the wire form of these materials is the variance in cold work remaining after the drawing process is completed. Finally, H25 has 10 wt\% nickel and 51 wt $\%$ cobalt. That $\mathrm{H} 25$ out performed the other four candidates is not unexpected because of the inherent wear resistance of cobalt based alloys.

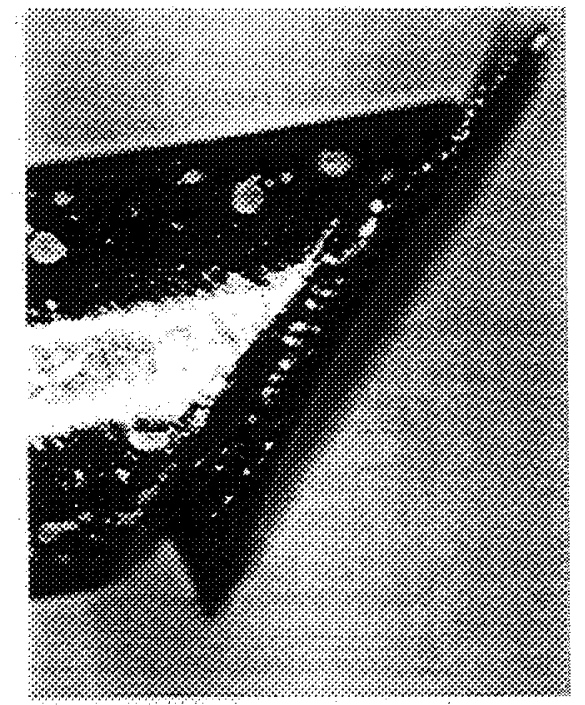

Figure $6: \mathrm{H} 214$ tuft after two hours of testing against plasma sprayed chrome carbide at $650^{\circ} \mathrm{C}\left(1200^{\circ} \mathrm{F}\right)$. 


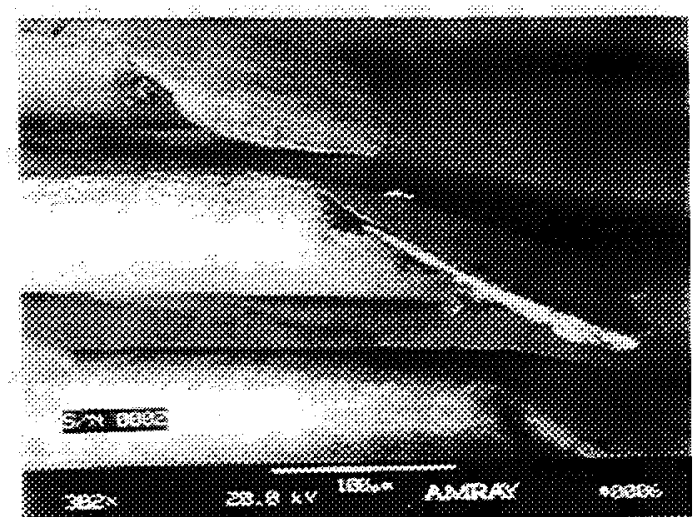

Figure $7: \mathrm{H} 25$ full scale brush seal bristle ends after running at $305 \mathrm{~m} / \mathrm{s}(1000 \mathrm{f} / \mathrm{s})$ against chrome carbide for eight hours at room temperature.

These alloys perform well in sliding wear environments because of their lubricous oxide formation $\left(\mathrm{CO}_{2} \mathrm{O}_{3}\right)$ and their resistance to galling.

Photographs of $\mathrm{H} 25$ and $\mathrm{H} 214$ bristle ends after full scale seal tests are shown in Figures 7 and 8. These seals were tested for eight hours in ambient air with a surface speed of $305 \mathrm{~m} / \mathrm{s}(1000 \mathrm{f} / \mathrm{s})$ and an initial interference of $0.51 \mathrm{~mm}(0.020 \mathrm{in}$.). For comparison purposes, Figure 9 shows the bristle end of a H25 tuft tested for fifty hours at $650^{\circ} \mathrm{C}\left(1200^{\circ} \mathrm{F}\right)$. As seen in both H25 tests, similiar wear morphology has occurred in both the full scale test and the tuft test. The H214 full scale and tuft test photographs (Figures $6 \& 8$ ) show the severe abrasive wear and bristle buckling experienced in both regimes.

Set interference tuft and brush seal segment tests conducted at one of the authors laboratories has been used to develop an analytical model of brush wear. The following equation has been used to

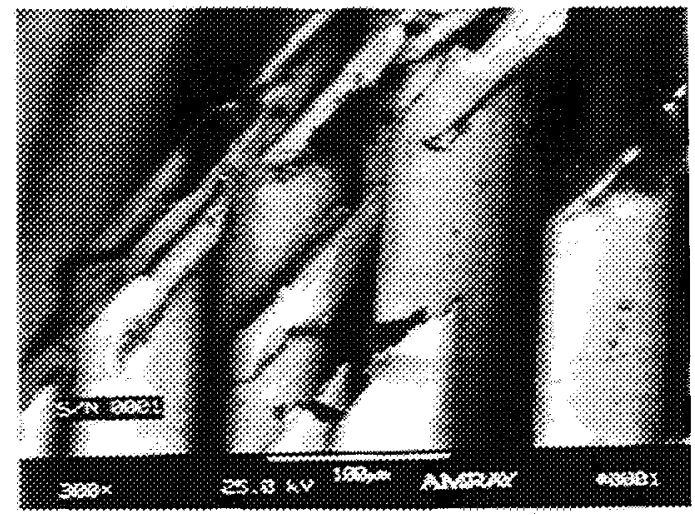

Figure 8 : H214 Full scale brush seal bristle ends after running at $305 \mathrm{~m} / \mathrm{s}(1000 \mathrm{f} / \mathrm{s})$ against chrome carbide for eight hours at room temperature.

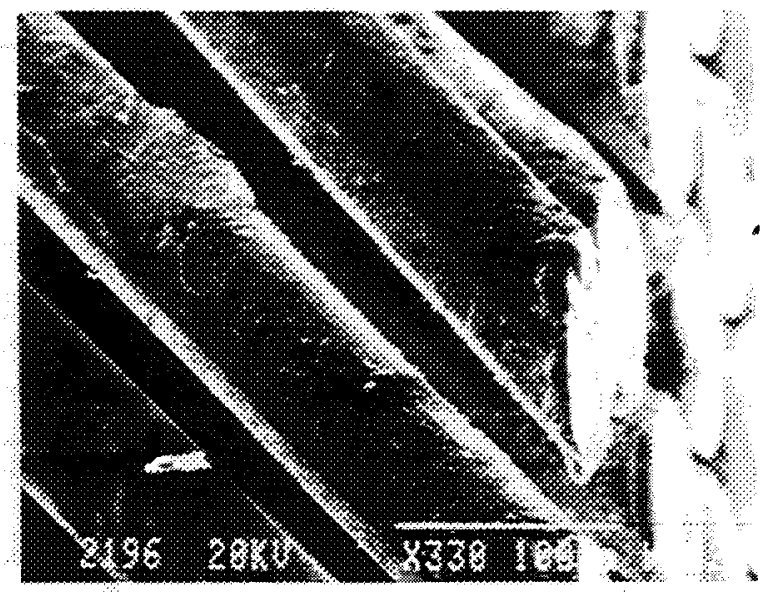

Figure 9 : $\mathrm{H} 25$ tuft test bristle ends after fifty hours of running against chrome carbide at $650^{\circ} \mathrm{C}\left(1200^{\circ} \mathrm{F}\right)$

characterize various brush/shaft coating material combinations:

$$
d=d_{0} \exp \left(\frac{t}{k}\right)
$$

Eq. 1

$$
\begin{array}{ll}
\mathrm{d}=\text { interference } & \mathrm{d}_{\mathrm{o}}=\text { initial interference } \\
\mathrm{t}=\text { time } & \mathrm{k}=\text { seal wear time constant }
\end{array}
$$

The time constants for $\mathrm{H} 25$ and $\mathrm{H} 214$ tested against chrome carbide are 58 and 34 respectively. While the relative ranking compares directly with the results of the tuft testing, the very poor results obtained with the $\mathrm{H} 214$ was unexpected.

Joumal Wear. The journal wear factors ranged from $2.3 \times 10^{-6} \mathrm{~mm}^{3} / \mathrm{N} \cdot \mathrm{m}$ for the $\mathrm{H} 214$ to a material deposit of $-1.0 \times 10^{-6} \mathrm{~mm}^{3} / \mathrm{N} \cdot \mathrm{m}$ (a negative wear factor implies a deposit of material) by the MA754. Journal wear for baseline H25 against bare I718 is $1.6 \times 10^{-7} \mathrm{~mm}^{3} / \mathrm{N} \cdot \mathrm{m}$. Figure 10 shows the journal wear compared for the chrome carbide and I718.

Hawthorne reported a combined wear rate of $1.5 \times 10^{-6} \mathrm{~mm}^{3} / \mathrm{N} \cdot \mathrm{m}$ for $\mathrm{H} 25$ against chrome carbide. Test conditions were $70 \mathrm{~m} / \mathrm{s}, 450^{\circ} \mathrm{C}\left(842^{\circ} \mathrm{F}\right)$ and 4.5 $\mathrm{N}(1 \mathrm{lbf})$ load. This compares to a combined wear rate of $0.5 \times 10^{-6} \mathrm{~mm}^{3} / \mathrm{N} \cdot \mathrm{m}$ for these tests. 


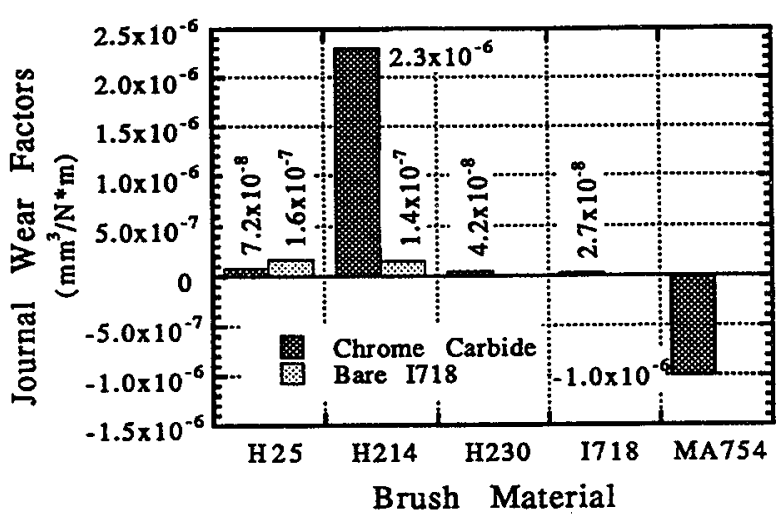

Figure 10 : Journal wear factors for five metallic wire samples tested against plasma sprayed chrome carbide and 1718 at $650^{\circ} \mathrm{C}\left(1200^{\circ} \mathrm{F}\right)$.

\section{Concluding Remarks}

The H25 against the plasma sprayed chrome carbide performed the "best" out of the five material pairs tested. This result agrees with other full scale brush seal tests 1,6 . The high nickel content alloys performed poorly compared to the alloys containing cobalt $(\mathrm{H} 25$ and $\mathrm{H} 230)$. Bristle flaring of the $\mathrm{H} 214$ can be detrimental to the sealing characteristics of the brush due to engine shaft transients resulting in bent bristles and gap formation between the seal and shaft. This gap will result in higher seal leakage in the same fashion as worn teeth or abradable in a labyrinth seal. With the appropriate tuft test configuration and equipment, brush seal material pairs can be accurately characterized at about $1 / 10^{\text {th }}$ the cost of full seal testing.

\section{References}

1. Mahler, F., and Boyes, E.,"The Application of Brush Seals in Large Commercial Jet Engines," AIAA paper 95-2617, 1995.
2. Steinetz, B.M., and Hendricks, R.C., "Engine Seal Technology Requirements to Meet NASA's Advanced Subsonic Technology Program Goals," AIAA paper 94-2698, 1994.

3. Flower, R.,"Brush Seal Development System," AIAA paper 90-2143, 1990.

4. Chupp, R.E., and Nelson, Lt. P.,"Evaluation of Brush Seals for Limited-Life Engines," AIAA paper 90-2140, 1990.

5. Holle, G.F., and Krishnan, M.R.,"Gas Turbine Engine Brush Seal Applications," AIAA paper 90-2142, 1990.

6. Atkinson, E., and Bristol, B.,"Effects of Material Choices on Brush Seal Performance," Lubrication Engineering, Volume 48, 1991.

7. Hendricks, R.C., Griffein, T.A., Bobula, G.A., Bill, R.C., Hull, D.R., and Csavina, K.R.,"Metallographic Analysis of Brush Bristle and Integrity Testing of Brush Seal in Shroud Ring of T-700 Engine," Army Research Laboratory Memorandum report ARL-MR-119, 1994.

8. Derby, J., and England, R.,"Tribopair Evaluation of Brush Seal Applications," AIAA paper 923715.

9. Hawthorne, H.M.,"Brush-on-disc simulation Tribotesting of materials for gas turbinecompliant seal components," Tribology International, Volume 27 Number 2, 1994.

10. Fellenstein, J.A., and DellaCorte, C.,"A New Tribological Test for Candidate Brush Seal Materials Evaluation," NASA TM-106753, 1995.

11. Sliney, H.E., and DellaCorte, C.,"'The Friction and Wear of Ceramic/Ceramic and Ceramic/Metal Combinations in Sliding Contact," Lubrication Engineering, Volume 50, 1993. 
Table 1: Chemical Composition of Wire Samples (wt\%)

\begin{tabular}{|l|c|c|c|c|c|l|}
\hline H25 & Co & $\mathrm{Ni}$ & $\mathrm{Cr}$ & $\mathrm{Fe}$ & $\mathrm{W}$ & OTHERS (< 6 wt\%) \\
\hline $\mathrm{H} 214$ & 51 & 10 & 20 & 3 & 15 & $\mathrm{Mn}, \mathrm{Si}, \mathrm{C}$ \\
\hline $\mathrm{H} 230$ & - & 75 & 16 & 3 & - & $\mathrm{Mn}, \mathrm{Si}, \mathrm{Al}, \mathrm{C}, \mathrm{B}, \mathrm{Zr}, \mathrm{Y}$ \\
\hline $\mathrm{I718}$ & 5 & 52.7 & 22 & 3 & 14 & $\mathrm{Mo}, \mathrm{Si}, \mathrm{Mn}, \mathrm{C}, \mathrm{Al}, \mathrm{B}, \mathrm{La}$ \\
\hline MA754 & - & 52.5 & 19 & 18.5 & - & $\mathrm{Mo}, \mathrm{Nb}, \mathrm{Ti}, \mathrm{Al}, \mathrm{C}, \mathrm{Cu}$ \\
\hline
\end{tabular}

Table 2: Wire Material Properties at $650^{\circ} \mathrm{C}$

\begin{tabular}{|l|c|c|c|c|}
\hline 325 & $\begin{array}{c}\text { Tensile Strength } \\
\text { Mpa (Ksi) }\end{array}$ & $\begin{array}{c}0.2 \% \text { Offset Yield } \\
\text { Strength } \\
\text { Mpa (Ksi) }\end{array}$ & $\begin{array}{c}1 \% \text { Creep Strength } \dagger \\
\text { Mpa (Ksi) }\end{array}$ & $\begin{array}{c}\text { Typical Stress } \\
\text { Rupture Strength } \dagger \\
\text { Mpa (Ksi) }\end{array}$ \\
\hline H214 & $745(108)$ & $330(48)$ & & $215(31)$ \\
\hline H230 & $829(120)$ & $589(85)$ & & $250(36)$ \\
\hline I718 & $670(97)$ & $270(39)$ & $110(16)$ & $185(27)$ \\
\hline MA754* & $1103(160)$ & $965(140)$ & $495(72)^{\ddagger}$ & $516(75)^{\ddagger}$ \\
\hline
\end{tabular}

* Longitudinal properties

$\dagger$ Based on bar testing at $760^{\circ} \mathrm{C}\left(1400^{\circ} \mathrm{F}\right)$ and 100 hours

$¥$ Based on bar testing at $704^{\circ} \mathrm{C}\left(1300^{\circ} \mathrm{F}\right)$ and 100 hours

Table 3: Standardized Brush Seal Tuft Test Conditions

\begin{tabular}{|c|c|}
\hline Variable & Value \\
\hline Temperature & $650^{\circ} \mathrm{C}\left(1200{ }^{\circ} \mathrm{F}\right)$ \\
\hline Surface Speed & $23.94 \mathrm{~m} / \mathrm{s}(78.54 \mathrm{ft} / \mathrm{s})$ \\
[Motor Speed] & {$[12,000 \mathrm{RPM}]$} \\
\hline Contact Force & $0.49 \mathrm{~N}(4.36 \mathrm{lbf})$ \\
{$[$ Test Load] } & {$[50 \mathrm{~g}]$} \\
\hline
\end{tabular}




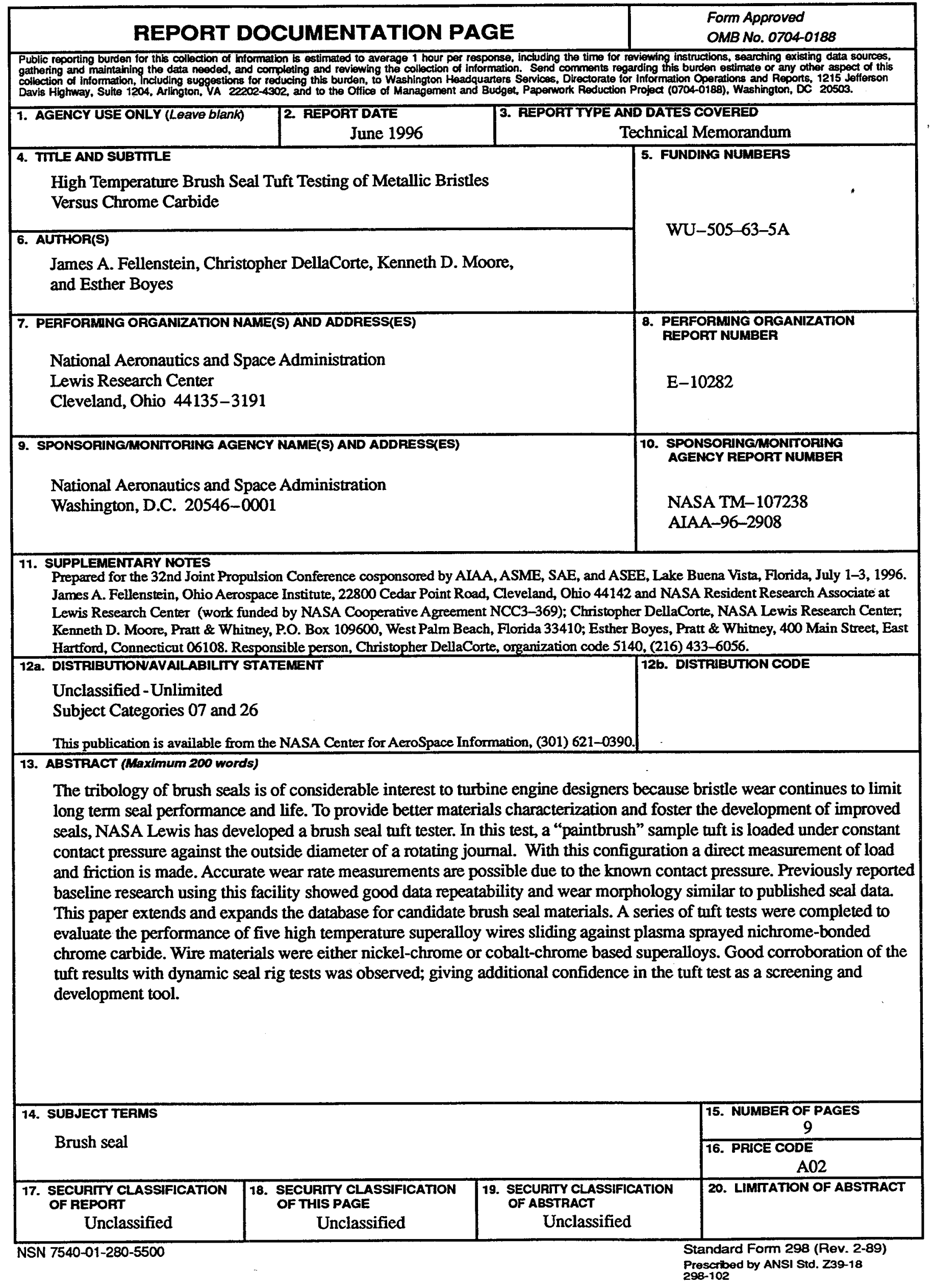


National Aeronautics and

Space Administration

\section{Lewis Research Center}

21000 Brookpark Rd.

Cleveland, $\mathrm{OH}$ 44135-3191

Official Business

Penally for Private Use $\$ 300$

POSTMASTER: If Undeliverable - Do Not Return 